\title{
Determinants of interest in using electronic money in Indonesia: evidence from Denpasar, Bali
}

\author{
Kadek Kharisma Suryandari* and Ni Putu Wiwin Setyari \\ Udayana University, Denpasar, Bali, Indonesia \\ *Correspondence email: kdkharisma26@gmail.com
}

\section{ARTICLE INFO}

- Research Article

\section{Article History}

Received 29 August 2020

Accepted 15 September 2020

Published 31 October 2020

\section{Keywords}

electronic money; risk perception; payment system; promotion

JEL Classification

E42; G32; M30

\begin{abstract}
Electronic money has received high attention from urban people in Denpasar, Bali. However, the use of electronic money is not yet fully known in relation to what factors influence user interest. This study aims to determine the relationship between factors that influence interest in using electronic money in Denpasar City, Bali Province. Data is obtained from online questionnaires on Google form, involve active users of Go-Pay, OVO, and Dana product. There are four variables observed including the risk perception, ease of use, benefit of use, and promotion. The research was worked with the confirmatory factor analysis. The results showed that majority of the users of electronic money are 20-25 years old, are female, have a bachelor's degree, and earn 2-4 million rupiahs. All variables show significant relationship to explains the interest in using electronic money. Interest in using electronic money is higher when the perception of risk is low, expand transactions, increases productivity and is supported by attractive promotion. The research suggests the attempts such as change in people's behavior to steadily use electronic money, regulation of the financial system stability to facility the use of electronic money and promotion are continuously strived so that users understand the risks and advantages of electronic money.
\end{abstract}

Citation: Suryandari, K. K. \& Setyari, N. P. W. (2020). Determinants of interest in using electronic money in Indonesia: evidence from Denpasar, Bali. Journal of Socioeconomics and Development, 3(2), 126-133. https://doi.org/10.31328/jsed.v3i2.1588

\section{INTRODUCTION}

Electronic money is a non-cash transaction facility that is receiving high attention from the public. This can encourage efficiency, effectiveness, and security of services in the various transaction needs. In Indonesia, electronic money service providers also offer many choices of payment applications to meet various transaction needs. Non-cash payment services have become increasingly popular with the support of smartphone use in the last five years in Indonesia. The rapid development of information technology and the internet has changed the payment model for consumers or other services in meeting their needs. The use of electronic money will provide benefits for users, service providers, and the government (Bank Indonesia, 2019).

Bank Indonesia has issued a monetary policy to facilitate the use of electronic money as a payment system. Related to the interest of government and Bank Indonesia, electronic money or e-money is one of the means to achieve the goal of building a cashless society. Bank Indonesia Regulation (PBI 20/2018) article 1 point 3 states that electronic money as a means of payment must meet the 
following elements: (i) issued on the basis of the value of money deposits held by the issuer, (ii) money is deposited electronically on the media server, and (iii) the value of electronic money managed by the issuer complies with banking rules and regulations. Electronic money can be transferred for payment transactions and/or fund transfers for its users.

Electronic money products that are popular in circulation include BCA Flazz, Mandiri E-Money, BRI Brizzi, and Tap Cash BNI. Those electronic money products are based on a chip, which is implanted in the card for payment purposes. Another kind of emoney is the server-based one, which does not use a card (chip). Server-based electronic money allows users to make buying and selling transactions quickly and safely without needing a card, for example GoPay, OVO, Dana, Go-Jek, Funds, Link Aja, Doku, and others. Until 2019, Bank Indonesia has officially issued 39 electronic money products. Electronic money issuers come from banks and non-bank financial institutions. The performance of non-bank issuers has shown improved performance, with activities monitored by Bank Indonesia to ensure safety and comfort for user.

Table 1. Electronic Transactions in Indonesia 2012-2019

\begin{tabular}{ccc}
\hline Year & Volume & Value \\
\hline & million unit & trillion rupiahs \\
2012 & 100.62 & 1.972 \\
2013 & 137.90 & 2.907 \\
2014 & 203.37 & 3.320 \\
2015 & 535.58 & 5.283 \\
2016 & 683.13 & 7.064 \\
2017 & 943.32 & 12.375 \\
2018 & $2,922.70$ & 47.199 \\
2019 & $5,226.70$ & 145.165 \\
\hline Source: Bank Indonesia (2019)
\end{tabular}

Table 1 shows a trend in the use of electronic transactions which is increasing every year. The use of electronic money will have an impact on the banking system and the implications for monetary policy. Electronic money transactions have a significant effect on increasing the circulation of money (Pambudi, 2020). This correlates with an increase in turnover and total production of goods and services in the national economy, as explained by Irving Fisher's theory which relates the money supply and total transactions of goods and services production (gross domestic product). With the use of electronic money, a person is assumed to have a little cash in his wallet, but brings more significant circulation of money with the transactions he does with electronic nominal money. Even so, although non-cash payments are said to be effective, users face obstacles related to psychological factors, safety, comfort, and public trust (Hidayat, 2006).

Collaborative research between the I-price Group and the App Annie analytics company states that Gojek is the largest electronic money user in Indonesia. Gojek electronic money users also make Go-Pay transactions and utilize other services from the Gojek application. The next rank is occupied by OVO. OVO is competing with LinkAja for the second place. In the second quarter of 2019, LinkAja's position was successfully shifted by a newcomer, Dana. Jenius's electronic money product was in fifth place, even though in the third quarter of 2018 it was in fourth place.

The initiative of using non-cash money will support increased financial inclusion. The government wants to realize financial sovereignty through financial inclusion policies that reach $50 \%$ of the population. However, the fact remains that many people still do not rely on non-cash currencies as a means of payment transactions.

Denpasar is the city with the highest population density in Bali Province. Urbanization of the population drives the rate of migration and increases economic activity, including the use of electronic money. The economy of Denpasar is centered on tourism development and its supporting services that rely on digital-based economic transactions. Still, the phenomenon of using electronic money for people is not yet fully known. Users do not yet fully understand the benefits of server-based electronic money and the extent to which it is used efficiently.

In general, users' interest in non-cash (electronic) transactions faces many problems. Data as of May 2019 shows that there are more than 2.9 million cards distributed in Bali, consisting of 317 thousand ATM cards, 2.3 million debit cards, and 361 thousand credit cards, with a total transaction value of 2.2 trillion rupiahs approximately. Constraints of the use of non-cash transactions are the culture or habits of people who still keep cash, especially those in rural or remote areas. The younger generation shows more non-cash transactions than the older generation. Other obstacles are the lack of telecommunications infrastructure to run Electronic Data Capture (EDC) machines, tug-of-war on 
Merchant Discount Rate (MDR), and card transaction fees. In fact, the use of electronic money is more profitable because the real value of money is relatively constant, free from the risk of physical damage to money (Tribun Bali, 2019).

The distribution of non-cash usage and transactions also still does not reach all business ventures. Transactions were found to be limited to MSMEs or in large stores (merchants) that have collaborated with electronic money issuers. They transact with consumers and suppliers of interconnected electronic money users. The use of digital transactions is determined by the user's behavioral interest, where the behavioral interest itself is determined by attitudes toward behavior and perceived usefulness (Davis, Bagozzi, \& Warshaw, 1989). The decision to use new technology is determined by the benefits gained and the perceived convenience, which is believed to be the basic determinant of the acceptance of a technology (Davis et al., 1989)

Various benefits of electronic money, such as convenience, benefits, and promotional benefits are provided to attract electronic money users. Promotions that provide benefits, generate satisfaction for users and they tend to reuse. The explanation of Silaen \& Prabawani (2019) shows that the promotional variable has a positive and significant effect on the interest in re-transactions of OVO electronic users in Semarang.

The use of server-based electronic money is getting higher interest than chip-based money in Denpasar. The publisher has carried out an aggressive promotion to attract more users to transact, by providing cash back or discounts. This phenomenon of the promotion of electronic money is very interesting to research, in addition to the benefits due to benefits and convenience.

This study aims to examine the relationship between determinants or factors that affect one's interest in using electronic money. The factors analyzed in this study are risk perception, ease of use, use benefit, and promotion.

\section{RESEARCH METHOD}

This study uses a survey approach to users of GoPay, OVO, and Dana electronic money in Denpasar. The electronic money issuers provide EDC machines spread in various shops or merchants in Denpasar.
The size of samples in this study is as many as 120 respondents who were determined based on the factor analysis module. The sample size considers an even effort to represent the three electronic money products (Sugiyono, 2016). The study uses 4 variables and a total of 12 indicators (Table 2 and Figure 1).

Tabel 2. Variables and Its Indicators Affecting Interest in Using Electronic Money

\begin{tabular}{ll}
\hline Variable & Indicator \\
\hline Risk Perception & Low risk of use (PR1) \\
& Good system security (PR2) \\
& Guarantee of security (PR3) \\
\hline Ease of Use & Easy to learn (KP1) \\
& Easy to get (KP2) \\
& Easy to use (KP3) \\
\hline Benefits of Using & Speeds up the transaction (MP1) \\
& Increase productivity (MP2) \\
& The efficiency of transaction (MP3) \\
\hline Promotion & Attractive and easy-to-use (P1) \\
& Increase of transactions (P2) \\
& Promotional benefits (P3)
\end{tabular}

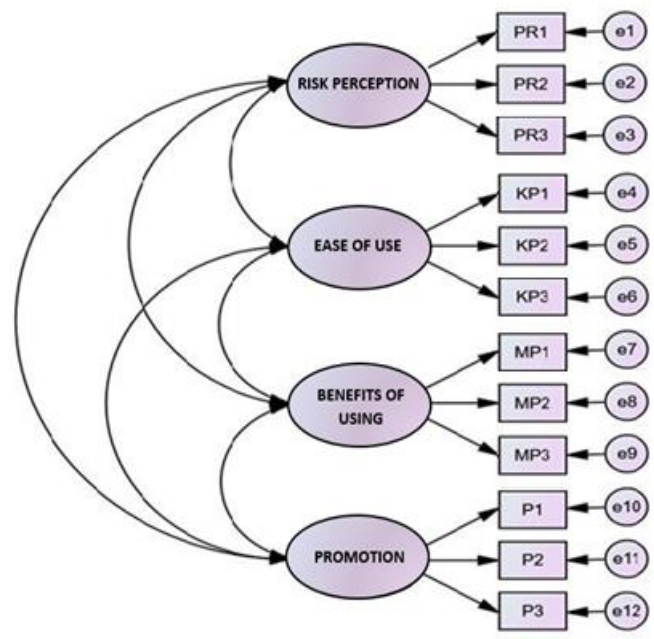

Figure 1. Model confirmatory factor analysis

This study defines the risk perception variable measured through indicators of low risk of use, good system security, and a good guarantee of transaction security. The ease of use variable is measured by feature indicators, namely easiness of learning, easiness of acquiring (downloading), and easiness of use for transactions. The benefits of use are related to the direct and indirect impacts of using electronic money, including faster transaction indicators, increased productivity, and efficient transactions. 
Promotional variables are related to product benefits such as promotional attractiveness, discounts or cash back, and promotional benefits. Indicators were assessed using a 5-point Likert scale.

The research was carried out during the Covid-19 pandemic, where the research instrument used a questionnaire distributed online using Google Form. The answers to the questions for each indicator are stated on a Likert scale with an ordinal score of 1 to 5 , which is 1 for strongly disagree, 2 for disagree, 3 for moderate, 4 for agree, and 5 for strongly agree.

Table 3. The Goodness of Fit Model

\begin{tabular}{lr}
\hline Criteria & Value \\
\hline Probability & $<0,05$ \\
CMIN/DF & $<2.0$ \\
RMSEA & $<0.8$ \\
CFI & $\geq 0,9$ \\
GFI & $\geq 0,9$ \\
RMR & $<0,05$ \\
\hline
\end{tabular}

This study used a confirmatory factor analysis (CFA) method. CFA is useful for determining the structure of the matrix, analyzing the relationship (correlation) between variables, and knowing the extent to which each variable can be explained by each indicator (Ghozali, 2012). CFA also helps test hypotheses of model specifications. The four stages of CFA (Hair. Black, Babin, \& Anderson, 2016) include defining each construct, building the model, testing the model, assessing the validity of the model. Analysis criteria of the goodness of fit (Table 3) were operated using the AMOS 21 software program.

\section{RESULT AND DISCUSSION}

\section{Characteristic of Respondent}

The characteristics of the respondents using electronic money are presented in Table 4. The table shows that most of the users of electronic money are in the 20-25 years old range. This age is productive and characterizes openness to the latest technological developments and being able to apply technology, especially gadgets. Electronic money transactions rely on modern and electronic technology using an internet connection. Meanwhile, more respondents were female than male. Also, the respondents with a bachelor's degree outnumbered those with other education levels. Obviously, electronic money users with education below high school cannot be found. This shows that they are generally well educated.

Tabel 4. Characteristics of Respondents

\begin{tabular}{|c|c|c|c|}
\hline \multirow[t]{2}{*}{ No } & \multirow[t]{2}{*}{ Variable observed } & \multicolumn{2}{|c|}{$\begin{array}{c}\text { Number of } \\
\text { Respondents }\end{array}$} \\
\hline & & people & $\%$ \\
\hline \multirow[t]{6}{*}{1} & Age & & \\
\hline & $<20$ years & 5 & 4.2 \\
\hline & 20-24 years & 100 & 83.3 \\
\hline & $25-29$ years & 13 & 10.8 \\
\hline & 30-34 years & 1 & 0.8 \\
\hline & $\geq 35$ years & 1 & 0.8 \\
\hline \multirow[t]{3}{*}{2} & Gender & & \\
\hline & Female & 77 & 64.2 \\
\hline & Male & 43 & 35.8 \\
\hline \multirow[t]{5}{*}{3} & Education & & \\
\hline & Senior High School & 11 & 9.2 \\
\hline & Diploma & 2 & 1.7 \\
\hline & Bachelor & 102 & 85.0 \\
\hline & Master or Magister & 5 & 4.2 \\
\hline \multirow[t]{8}{*}{4} & Occupation & & \\
\hline & Government Employees & 3 & 2.5 \\
\hline & Private Employees & 56 & 46.7 \\
\hline & Student & 29 & 24.2 \\
\hline & Professional & 7 & 5.8 \\
\hline & Entrepreneur & 12 & 10.0 \\
\hline & Other Profession & 11 & 9.2 \\
\hline & Not Work & 2 & 1.7 \\
\hline \multirow[t]{7}{*}{5} & Income & & \\
\hline & $<\mathrm{Rp} 2,000,000$ & 19 & 15.8 \\
\hline & $\mathrm{Rp2}, 000,001-\mathrm{Rp} 4,000,000$ & 47 & 39.2 \\
\hline & $\mathrm{Rp} 4,000,001-\mathrm{Rp} 6,000,000$ & 34 & 28.3 \\
\hline & Rp6,000,001 - Rp8,000,000 & 11 & 9.2 \\
\hline & $R p 8,000,001-R p 10,000,000$ & 4 & 3.3 \\
\hline & $>\mathrm{Rp} 10,000,000$ & 5 & 4.2 \\
\hline \multirow[t]{5}{*}{6} & Domicile & & \\
\hline & West Denpasar & 35 & 29.2 \\
\hline & South Denpasar & 26 & 21.7 \\
\hline & East Denpasar & 32 & 26.7 \\
\hline & North Denpasar & 27 & 22.5 \\
\hline \multirow[t]{4}{*}{7} & Product of electronic money & & \\
\hline & Go-Pay & 52 & 43.3 \\
\hline & Ovo & 60 & 50.0 \\
\hline & Dana & 8 & 6.7 \\
\hline \multirow[t]{7}{*}{8} & Frequency of Use & & \\
\hline & 1 time a month & 15 & 12.5 \\
\hline & 2-5 times a month & 41 & 34.2 \\
\hline & 6-10 times a month & 25 & 20.8 \\
\hline & $11-15$ times a month & 18 & 15.0 \\
\hline & > 16 times a month & 21 & 17.5 \\
\hline & Total respondent & 120 & 100.0 \\
\hline
\end{tabular}

In term of income, most electronic money users earn around 2-4 million rupiahs. This income is in accordance with the status of the respondents, who on average are not married or may not have family members, so the income is only used for personal needs. Meanwhile, most users reside in West Denpasar. The most widely used electronic money is the OVO product. Each electronic money product has 
relatively similar characteristics and usage methods. However, what distinguish them are the marketing strategy, the transaction accepting shop (which works with electronic money issuers), and the kinds of promotions offered. From the frequency of use, most respondents use electronic money 2-5 times a month. This shows that they are interested in using electronic money in their activities.

\section{Model Specification}

The measurement results of the outer model are presented in Table 5. This measurement is intended for the reliability and validity of all the indicators that make up the model. The results also show that the analysis can be carried out without modification or adjustment of the model because all criteria indicate the results' reliability and validity.

Table 5. Outer Model Measurement

\begin{tabular}{lccc}
\hline Indicator & $\begin{array}{c}\text { Loading } \\
\text { Factor }\end{array}$ & AVE & CR \\
\hline Low risk of use (PR1) & 0.790 & 0.91 & 0.97 \\
Good system security (PR2) & 0.836 & & \\
Guarantee of security (PR3) & 0.856 & & \\
\hline Easy to learn (KP1) & 0.801 & 0.91 & 0.97 \\
Easy to get (KP2) & 0.823 & & \\
Easy to use (KP3) & 0.854 & & \\
\hline Speeds up the transaction (MP1) & 0.794 & 0.86 & 0.95 \\
Increase productivity (MP2) & 0.815 & & \\
The efficiency of transaction (MP3) & 0.696 & & \\
\hline Attractive and easy-to-use (P1) & 0.866 & 0.89 & 0.96 \\
Increase of transactions (P2) & 0.786 & & \\
Promotional benefits (P3) & 0.784 & & \\
\hline CR: composite reiability, AVE: average varince
\end{tabular}

CR: composite reliability, AVE: average variance extracted

Table 5 shows that the loading value is higher than 0.5 , or even more than 0.7 . These results indicate that the indicators on each factor or variable meet the validity to form a model. Based on Ghozali (2012), the factor loading value is (i) more than 0.30 , meaning it meets the minimum level, (ii) more than 0.40 , meaning more important, and (iii) above 0.50 , meaning that it is practically important.

In the risk perception variable, the most influential indicator is security assurance (PR3) with a correlation coefficient (loading factor) of 0.856 . In the ease of use variable, the most vital indicator is the ease of use of transactions (KP3) with a correlation coefficient of 0.854 . Meanwhile, for the variable of usage benefit, the most substantial indicator is the increase in productivity (MP2) with a coefficient of 0.815 . Finally, the promotion variable is more influenced by the attractiveness and ease of use (P1) indicators with a correlation coefficient of 0.866. Table 5 shows that the AVE values of all variables exceed the cut-off 0.7. This means that each construct variable can be relied on to explain the relationship between the variables in the model. In other words, the model characterizes a valid and convergent relationship. Meanwhile, the CR value of all variables exceeds exceed the cut-off value of 0.6. This value indicates that the relationship between variables in the model meets reliability.

\section{Factors Affecting Interest in Using Electronic Money}

Measurement of the inner model is carried out to determine the relationship between each construct variable, as presented in Table 6 . In general, the relationship between variables finds a very significant correlation coefficient ( $p$-value less than 0.05 ).

Table 6. Correlation between variables

\begin{tabular}{lc}
\hline Construct Correlation & Estimates \\
\hline Risk Perception - Ease of Use & 0.449 \\
Risk Perception - Benefit of Use & 0.409 \\
Risk Perception - Promotion & 0.482 \\
Ease of Use - Benefit of Use & 0.845 \\
Ease of Use - Promotion & 0.797 \\
Benefit of Use - Promotion & 0.769 \\
\hline
\end{tabular}

The parameter estimation of the relationship between risk perception and ease of use shows a significant positive value of 0.449 . This shows that the relationship between risk perception and ease of use affects an interest in using electronic money. Mbogo (2010) studied various factors that contributed to the successful use of non-cash payments by micro-enterprises in Kenya. He found that interest was determined by the ease of technology, accessibility, cost, and safety factors. Ease of accessibility including ease of use plays a role in technology adoption despite its risks (Pavlou, 2003). Convenience does not necessarily affect user interest without a guarantee of risk-handling or security regarding user data. Potential risks always arise behind the use of technology (Ackermann, Miede, Buxmann, \& Steinmetz, 2011). Users certainly expect a low risk of using electronic money. Risks are related to system security and transactions both directly at cashier outlets and through applications on smartphones. The lower the risk perception and the easier to use the electronic money is, the more public interest in electronic money will be. 
The relationship between the perceived risk and benefit variables of use shows a correlation coefficient value of 0.409 . This shows that perceptions of the risks and benefits of use influence the interest in using electronic money. These findings confirm the research results of Priyono (2017) and Gefen \& Straub (2000), where the benefits of use have the strongest influence on user interest. The results of this study indicate that OVO products are considered beneficial for their users, with an average usage frequency of 2-5 times a month.

It is very important to understand that there is a relationship between opportunity, uncertainty, and the possibility of getting an advantage (Komiak \& Benbasat, 2006; Mayer, Davis, \& Schoorman, 1995). Uncertainty regarding the risk of using electronic money can increase if users cannot measure product quality and rely solely on available information. Therefore, electronic money issuers must provide transparent information that assures users. For users of electronic money, they need to ensure security and discover the quality and benefits of using electronic money (Oktaviani, Faeni, Faeni, \& Meidiyustiani, 2019). When certainty about security is not achieved, it will decrease the interest in using electronic money.

The relationship between risk perception and promotion variables shows a correlation coefficient of 0.482 . This shows that risk perception and promotion affect the interest of electronic money users. The higher risk causes someone to be more afraid of transacting with electronic money, and vice versa. Risks should be minimized by electronic money issuers or the government by ensuring guarantees to users. Things that can be promoted are sales discounts at various merchants or stores to increase interest in using electronic money. Promotion can be done through advertising, publication, and public relations functions (Lupiyoadi and Hamdani, 2011)

Between the ease of use variable and the benefits of use, a correlation coefficient of 0.845 was found. These two variables affect interest in using electronic money. According to Davis et al. (1989) and Venkatesh \& Davis (2000), the perceived ease is proven to affect the interest in using electronic money through perceived usefulness. This shows that the ease of using electronic money is in line with user expectations. If the use of electronic money is easier than other similar products, users will tend to choose an electronic money product that is easier to use.

The estimated parameter of the relationship between the ease of use and promotion variables shows a correlation coefficient of 0.797 . These findings suggest that ease of use is associated with the promotion in influencing interest in using electronic money. Ease of use is a belief in electronic money technology, where an individual believes that it is easy to use and understand, as well as practical. The ease of use of electronic money will trigger an increase in user interest. This convenience includes access to electronic money accounts through various platforms or media on the user's gadget, including convenience in transactions. This convenience should be promoted to increase consumer interest in fulfilling their needs (Lupiyoadi and Hamdani, 2011). Cooperation between electronic money issuers and transaction providers is developed for payment gateway facilities for electricity, telephone, and other public utilities.

\section{Research Implication}

The development of economic activity in Indonesia is entering the digital economy era, with the increasing use of electronic money. This research has resulted in the following implications or suggestions.

Changes in people's behavior and habits are encouraged and motivated in order to implement electronic payment system technology. New innovations have appeared in digital payment transactions in the form of financial technology (fintech), especially the use of server-based electronic money. The advantage of non-cash payments is the speed of transactions, which encourages the rate of money circulation and increases the production of goods and services (Popovska-Kamnar, 2014). Promotions such as discounts can encourage people to buy electronic money products.

Bank Indonesia uses prudent monetary criteria to regulate the use of electronic money. Money circulation is an important indicator of maintaining monetary stability. The issuance of non-cash instruments needs to be properly maintained and monitored with an orientation to stability. In line with the increase in transactions for money payment instruments, Bank Indonesia needs to regulate its 
effects on inflation and interest rates to be controlled in the context of financial system stability.

Electronic money issuers as technology developers in the future need to pay attention to risk perceptions, ease of use, benefits of use, and promotion to increase public interest. According to Hasniawati, Lase, \& Hutabarat, (2020), the socioeconomic characteristics which include education, age, income, and the purpose or function of the transaction affect the use of non-cash electronic payments. Socialization and promotion continuously strive so that users understand the risks, advantages, or disadvantages. Kochergin (2017) argued that the widespread use of electronic money is due to its speed and convenience. Electronic money issuers should pay attention to safeguarding the non-cash payment system.

\section{CONCLUSION AND SUGGESTION}

The results of this study show that majority of the users of electronic money are 20-25 years old female, holding a bachelor's degree, earning 2-4 million rupiahs, and using electronic money 2-5 times a month. Research also found that risk perception is determined primarily by the assurance of transaction security. The ease of use of electronic money is mainly influenced by the ease of transactions. Usage benefits are determined by increased productivity. Meanwhile, promotion is largely determined by the attractiveness of the promotion and the ease of use of electronic money.

This study also produces a constructive model that explains the relationship between perceived risk, ease of use, benefits of electronic money, and promotion. Interest in using electronic money is higher when the perception of risk is low, as well as when the e-money helps speed up transactions, increases productivity, and offers attractive promotions.

Furthermore, this research provides suggestions, including (i) change in people's behavior to understand and use electronic money wisely, (ii) regulation of the use of electronic money in the context of financial system stability, (iii) continuous socialization and promotion so that users understand the risks and advantages of the non-cash payment system.

\section{REFERENCES}

Ackermann, T., Miede, A., Buxmann, P., \& Steinmetz, R. (2011). Taxonomy of technological IT outsourcing risks: support for risk identification and quantification. In 19th European Conference on Information Systems, ECIS 2011. Retrieved from

https://core.ac.uk/download/pdf/6820393.pdf

Bank Indonesia. (2019). Publication Statistik Sistem Pembayaran.

https://www.bi.go.id/id/statistik/sistem-

pembayaran/uang-

elektronik/contents/transaksi.aspx. Accessed on 10 July 2020.

Davis, F. D., Bagozzi, R. P., \& Warshaw, P. R. (1989). User acceptance of computer technology: a comparison of two theoretical models. Management Science, 35(8), 982-1003. https://doi.org/10.1287/mnsc.35.8.982.

Gefen, D., \& Straub, D. (2000). The relative importance of perceived ease of use in IT adoption: a study of e-commerce adoption. Journal of the Association for Information Systems, 1(1), 1-27. https://doi.org/10.17705/1jais.00008

Ghozali, I. (2012). Aplikasi Analisis Multivariate dengan Program IBM SPSS. Edisi 8. Semarang: Universitas Diponegoro. https://books.google.co.id/books?id=JdqJAQAACA AJ

Hair, J. F., Sarstedt, M., Ringle, C. M. \& Mena, J. A. (2012). An assessment of the use of partial least squares structural equation modeling in marketing research. J. of the Acad. Mark. Sci. 40, 414-433. https://doi.org/10.1007/s11747-0110261-6

Hair. J. F., Black, W. C., Babin, B. J. and Anderson, R. E. (2016). Multivariate Data Analysis. 7th Edition, Pearson Education, Upper Saddle River https://books.google.co.id/books?id=LKOSAgAAQ BAJ

Hasniawati, N. A., Lase, E. R., \& Hutabarat, A. R. (2020). Indonesian household payment choice: a nested logit analysis. Journal of Central Banking Theory and Practice. 9(1), 291-313 https://doi.org/10.2478/jcbtp-2020-0032

Hidayat, A. (2006). Upaya Meningkatkan Penggunaan Alat Pembayaran Non Tunai Melalui Pengembangan E-Money. Working Paper Bank Indonesia. Retrieved from https://books.google.co.id/books/about/Upaya_m 
eningkatkan_penggunaan_alat_pemba.html?id=U 9wzmwEACAAJ\&redir_esc $=y$

Kochergin, D. A. (2017). Development and regulation of electronic money systems in asian financial centers. World Economy and International Relations, 61(7), 54-63. https://doi.org/10.20542/0131-2227-2017-61-754-63

Komiak, S. Y. X., \& Benbasat, I. (2006). The effects of personalization and familiarity on trust and adoption of recommendation agents. MIS Quarterly: Management Information Systems, 30(4), https://doi.org/10.2307/25148760

Lupiyoadi, R dan Hamdani, A. (2011). Manajemen Pemasaran Jasa. Salemba Empat. Edisi kedua. Retrieved from https://opac.perpusnas.go.id/DetailOpac.aspx?id $=918109$

Mayer, R. C., Davis, J. H., \& Schoorman, F. D. (1995). An integrative model of organizational trust. Academy of Management Review, 20(3), 709-734.

https://doi.org/10.5465/amr.1995.9508080335

Mbogo, M. (2010). The impact of mobile payments on the success and growth of micro-business: the case of M-Pesa in Kenya. Journal of Language, Technology \& Entrepreneurship in Africa, 2(1), 182-203. https://doi.org/10.4314/jolte.v2i1.51998

Oktaviani, R. F., Faeni, D. P., Faeni, R. P., \& Meidiyustiani, R. (2019). Implementation of mobile payment in Indonesia. International Journal of Recent Technology and Engineering. 8(2S4), 863-866 https://doi.org/10.35940/ijrte.B1172.0782S419

Pambudi, S. A. (2020). Analysis the effect of electronic money use on velocity of money: evidence from indonesia. Jurnal Ilmu Ekonomi Terapan, 5(1), 42-58. http://dx.doi.org/10.20473/jiet.v5i1.19626
Pavlou, P. A. (2003). Consumer acceptance of electronic commerce: Integrating trust and risk with the technology acceptance model. International Journal of Electronic Commerce, 7(3), 101-134. https://doi.org/10.1080/10864415.2003.1104427 5

Popovska-Kamnar, N. (2014). The use of electronic money and itsimpact on monetary policy. Journal of Contemporary Economic and Business Issues, $1(2)$,

79-92. https://www.econstor.eu/bitstream/10419/14746 0/1/86795244X.pdf

Priyono, A. (2017). Analisis pengaruh trust dan risk dalam penerimaan teknologi dompet elektronik Go-Pay. Jurnal Siasat Bisnis, 21(1), 88-106. https://doi.org/10.20885/jsb.vol21.iss1.art6

Silaen, E., \& Prabawani, B. (2019). Pengaruh persepsi kemudahan menggunakan e-wallet dan persepsi manfaat serta promosi terhadap minar beli ulang saldo e-wallet Ovo. Jurnal Ilmu Adminnistrasi Bisnis. 8(4), 155-163. Retrieved from

https://ejournal3.undip.ac.id/index.php/jiab/articl e/view/24834

Sugiyono. (2016). Metode Penelitian Bisnis (Pendekatan Kuantitatif, Kualitatif, dan R\&D). Bandung: Alfabeta. Retrieved from https://books.google.co.id/books?id=0xmCnQAAC AAJ

Tribun Bali. (2019). Program diskon dapat merangsang penggunaan uang elektronik. https://balitribune.co.id/content/program-diskondapat-merangsang-penggunaan-uang-elektronik. Accessed on 24 September 2019.

Venkatesh, V., \& Davis, F. D. (2000). A theoretical extension of the technology acceptance model: four longitudinal field studies. Management Science, 46(2), 186-204. https://doi.org/10.1287/mnsc.46.2.186.11926 